\section{HSE}

Historia Social y de la Educación

Social and Education History
Hipatia Press

www.hipatiapress.com

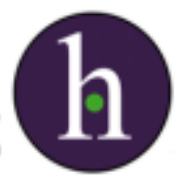

Instructions for authors, subscriptions and further details:

http://hse.hipatiapress.com

\title{
Childhood, Orphans and Underage Heirs in Medieval Rural Englang
}

Maria del Socorro Ocampo Castillo ${ }^{1}$

1) Universitat de Barcelona

Date of publication: June $23^{\text {th }}, 2019$

Edition period: June 2019-October 2019

To cite this article: Ocampo Castillo, M.S. (2019). Childhood, Orphans and Underage Heirs in Medieval Rural England [Review of the book]. Social and Education History, 8(2), 219-222. doi: 10.17583/hse.2019.4293

To link this article: http://dx.doi.org/10.447/hse.2019.4293

\section{PLEASE SCROLL DOWN FOR ARTICLE}

The terms and conditions of use are related to the Open Journal System and to Creative Commons Attribution License (CC-BY). 


\section{Review (I)}

Müller, Miriam. (2019). Childhood, Orphans and Underage Heirs in Medieval Rural England. Switzerland: Palgrave MacMillan

his book is the result of a research conducted by Dr. Miriam Müller, $\checkmark$ Lecturer in Medieval History from the University of Birmingham Department of History. The main focus in her work is extend the _ current knowledge about childhood in medieval rural England. For this purpose, she analyzes orphans and underage heirs' situation in the Black Death age. At the same time that the findings are presented throughout the chapters, seeks to awaken interest in expanding research on medieval rural environments as the purpose of demystifying the dichotomies that she believes persist around childhood in environments not urban. Her reflections and critical views have the intentions to contribute to current childhood studies and claiming the role of children in society even in that time.

The Introduction is presented in Chapter 1. Firstly, some dichotomies immersed in the contributions of other authors to childhood in the rural and urban environments are analyzed. On the one hand, Müller seeks to demystify the romantic idea sustained from the relationship with children and nature in rural settings. For this, she presents the difficulties that childhood faced during the period of the plague and explains the conditions of inequality of that moment. On the other hand, she clarifies that the concept of childhood is not a modern construction. Since the Middle Ages, children had an active value in society.

In Chapter 2, Vulnerable Members of the Community, explores the definition of childhood and describes the context of communities and lordships. The first part of the chapter explains how the examinations of how villagers felt about orphans and underaged heirs gives some insight into the attitude to childhood in general. This examination considers the period in which children acquire autonomy, that is, the moments of transition towards youth and adulthood. This consideration starts from the recognition of the economic value that is acquired and the conditions of social class and gender that influenced the determination of the level of maturity acquired. So, 
unlike our current time, the conception of "Majority Age" appeared much more flexible in the Middle Ages.

Chapter 3, Inheritance, Rights and Good, provides an approach to rural childhood through the analysis of the homes, assets and rights of the heirs and minors. The researcher pursues to associate the welfare and standard of living of child heir with the size of their holdings. Through the analysis of the inventory assets of the heirs under the age, tries to reconstruct the characteristics of the children's game and the entertainment activities.

A more in-depth discussion about the characteristics of orphans and underage heirs is presented in Chapter 4, Looking after the Underaged Heirs. Appealing to different sources of information, both demographic and anthropological, the author tries to explain more widely the characteristics of orphaned children. In doing so, she studies gender and contextual differences. Therefore, it is important to remember that patriarchal organizational structures did not occur in the same way in urban areas as in rural areas.

Chapter 5 Plotting out a Living, shows in a broader way the vicissitudes that children face as collateral victims of the plague. The first chapter section, Kinship Networks and Match Makers, describes the guardians influence in children relations and how responsibilities about orphans and heir led to abuses in several cases. Two sections more into this chapter explains the characteristics and importance of education in the rural environment.

Conclusions are exposed in Chapter 6, in addition to making a recount of the main findings that are shown about the investigation of rural childhood of the Middle Ages, the author shows her work as a critical contribution towards the understanding of childhood. She strongly emphasizes that his work is not intended to be a mere contribution to the chronological description of childhood, but rather to raise awareness about the great value that children and young people have had and have in shaping our structures and social development. 
This work seeks to awaken interest in research about childhood from an approach capable of overcoming androcentrism and devoid of preconceptions and preconceptions with evidence. Therefore, it opens the way to research in different contexts, understanding that the points in common and the discords are those that manage to expand the knowledge of the past reality and transfer it to the present.

Maria del Socorro Ocampo Castillo

Universitat de Barcelona mariaocampo1390@gmail.com 